University of Montana

ScholarWorks at University of Montana

$6-2003$

\title{
Differences in Cottonwood Growth Between a Losing and a Gaining Reach of an Alluvial Floodplain
}

\author{
Mary J. Harner \\ Jack Arthur Stanford \\ The University of Montana, jack.stanford@umontana.edu
}

Follow this and additional works at: https://scholarworks.umt.edu/biosci_pubs

Part of the Biology Commons

Let us know how access to this document benefits you.

\section{Recommended Citation}

Harner, Mary J. and Stanford, Jack Arthur, "Differences in Cottonwood Growth Between a Losing and a Gaining Reach of an Alluvial Floodplain" (2003). Biological Sciences Faculty Publications. 317. https://scholarworks.umt.edu/biosci_pubs/317

This Article is brought to you for free and open access by the Biological Sciences at ScholarWorks at University of Montana. It has been accepted for inclusion in Biological Sciences Faculty Publications by an authorized administrator of ScholarWorks at University of Montana. For more information, please contact scholarworks@mso.umt.edu. 


\title{
DIFFERENCES IN COTTONWOOD GROWTH BETWEEN A LOSING AND A GAINING REACH OF AN ALLUVIAL FLOODPLAIN
}

\author{
MARY J. HARneR ${ }^{1}$ AND JaCk A. Stanford \\ Flathead Lake Biological Station, Division of Biological Sciences, The University of Montana, 311 Bio Station Lane, \\ Polson, Montana 59860-9659 USA
}

\begin{abstract}
Interstitial flow of river (hyporheic) water influences algal productivity, benthic assemblages, and locations of fish spawning. However, little is known of the effects of hyporheic flow on the growth of riparian vegetation. By increasing water availability and nutrient delivery, regional upwelling of hyporheic water may increase the growth of terrestrial vegetation. We tested and accepted the hypothesis that cottonwood trees (Populus trichocarpa) in a gaining reach of an alluvial floodplain grow faster than trees in a losing reach by comparing basal areas and ages on an expansive floodplain in western Montana (USA). Trees in the gaining reach had basal areas twice the size of the trees in the losing reach, after correcting for tree age. In addition, the carbon-to-nitrogen ratios in leaves were $16 \%$ lower in the gaining reach. Lower cottonwood stem densities, deeper layers of fine sediments, and a higher water table occurred in the gaining compared to the losing reach. Each of these variables was significantly correlated with tree growth and likely interacted to influence the productivity of cottonwoods. We concluded that hydration and fertilization of riparian trees likely is mediated by hyporheic flow.
\end{abstract}

Key words: cottonwood; dendrochronology; floodplain; groundwater; growth; hyporheic; interstitial flow; Montana, USA; Populus; riparian; tree rings.

\section{INTRODUCTION}

Alluvial floodplains are dynamic regions that are shaped by repeated erosion and deposition of sediments, inundation during floods, and complex groundwater hydrology. Cottonwood trees occur in the changing habitats within floodplains and are a dominant riparian tree species throughout western North America (Braatne et al. 1996). Scour by flooding creates the bare surfaces that cottonwoods require for seed germination (Bradley and Smith 1986, Scott et al. 1996). Availability of water within the root zone controls the survivorship of seedlings (Bradley and Smith 1986, Segelquist et al. 1993, Mahoney and Rood 1998) and the maintenance of mature stands (Busch and Smith 1995, Scott et al. 1999, Horton et al. 2001). Rhizosphere water content is influenced by soil texture and depth of the alluvial aquifer, which vary spatially and temporally on naturally functioning floodplains (Mahoney and Rood 1998, Petts et al. 2000).

Although cottonwood responses to river dynamics, especially flooding and the availability of groundwater, are well documented (Braatne et al. 1996), little is known about how hyporheic flow affects the growth of cottonwood trees. Hyporheic zones are defined as subsurface areas where surface and groundwater mix (Stanford and Gaufin 1974). Surface water enters hy-

Manuscript received 24 September 2001; revised 22 December 2002; accepted 29 December 2002. Corresponding Editor: W. J. Platt.

1 Present address: Department of Biology, University of New Mexico, Albuquerque, New Mexico 87131 USA. E-mail: mharner@unm.edu porheic flow (downwells) in losing or effluent reaches of rivers, such as at the upstream end of floodplains (Stanford and Ward 1988). This groundwater may flow rapidly through the floodplain, if the alluvium has high hydraulic conductivity, and it may return to surface flow (upwell) in gaining or influent reaches (Poole et al. 2002). Upwelling groundwater often contains more nitrogen $(\mathrm{N})$ and phosphorus $(\mathrm{P})$ relative to surface water as a result of metabolism by microorganisms living within the interstitial spaces (Grimm and Fisher 1984, Dahm et al. 1998). Nutrients in upwelling groundwater may become available to riparian plants through subsurface flow paths that extend from active channels into riparian forests (Triska et al. 1993, Wondzell and Swanson 1996).

In this study, we compared the growth rates of black cottonwood trees (Populus trichocarpa T. \& G. ex Hook) between regions of contrasting hydrology on the Nyack Flood Plain of the Middle Fork of the Flathead River, Montana. Previous research on this floodplain has shown that upwelling hyporheic water in the gaining reach contains more soluble reactive phosphorus and nitrate than surface water (Bansak 1998, Ellis et al. 1998, Craft et al. 2002). We were interested in determining if this upwelling water produced a fertilization effect on cottonwood trees. We hypothesized that cottonwood trees grow faster in the gaining reach compared to trees in the losing reach. Because a number of variables interact to control the growth of cottonwoods, we measured biological (age, basal area, and tree density) and physical factors (depth of fine sediments, seasonal water table variation, and plot eleva- 


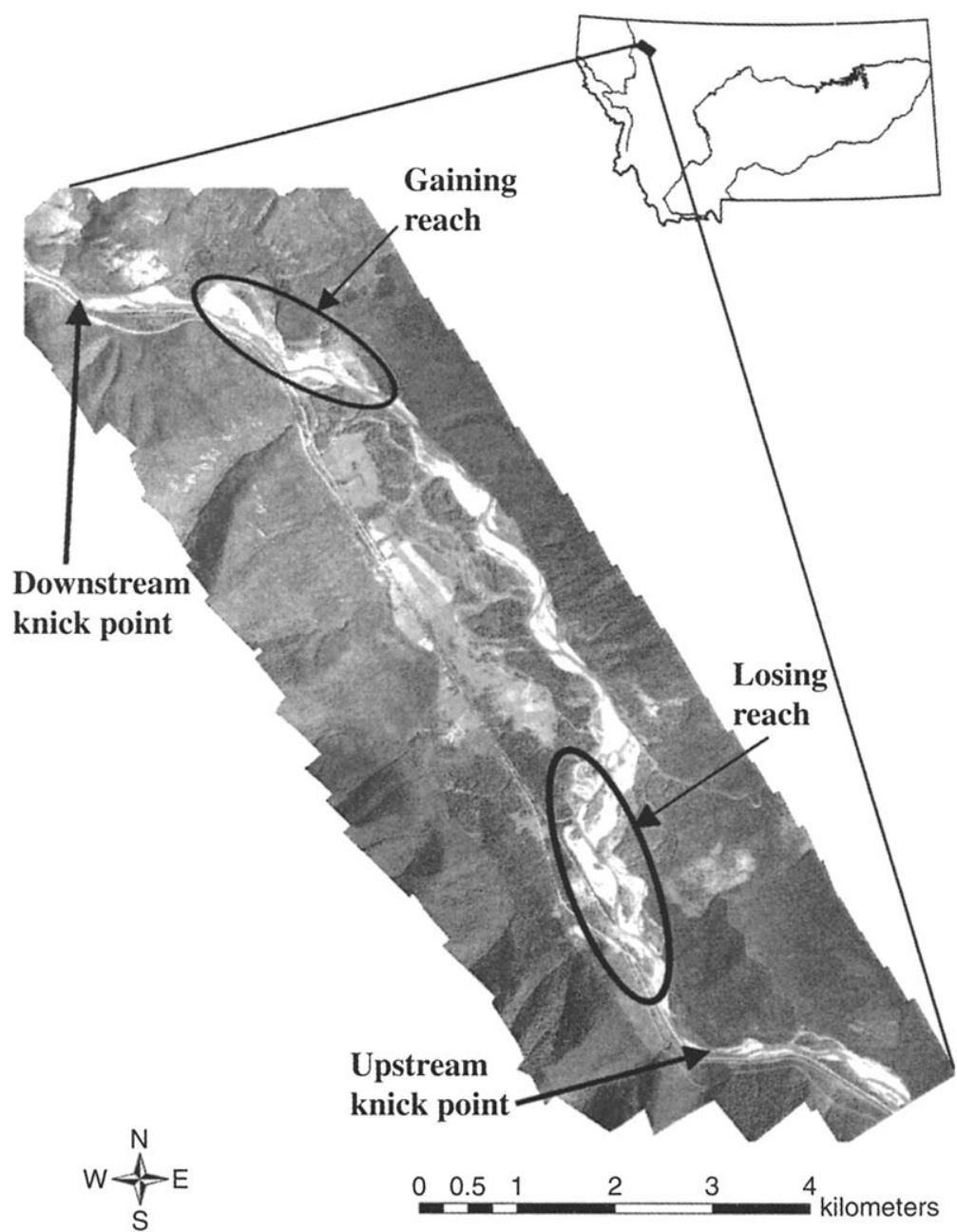

FIG. 1. The Nyack Flood Plain of the Middle Fork of the Flathead River, Montana, showing the primary sampling areas in the gaining and losing reaches. The image is a spatially explicit multispectral mosaic taken in August 1999.

tions above base flow) in both reaches. We also analyzed carbon $(\mathrm{C})$, nitrogen $(\mathrm{N})$, and phosphorus $(\mathrm{P})$ concentrations (Elser et al. 2000) in cottonwood leaves from downwelling and upwelling areas to compare leaf chemistry between the losing and the gaining reaches to determine if trees in the gaining reach had access to nutrients unavailable to trees in the losing reach.

\section{Methods}

\section{Study site}

The Nyack Floodplain (Nyack) is located in northwestern Montana $\left(48^{\circ} 29^{\prime} \mathrm{N}, 114^{\circ} 00^{\prime} \mathrm{W}\right)$, on the Middle Fork of the Flathead River, a fifth-order, unregulated river (Fig. 1). The hydrograph is dominated by snowmelt, with a daily average discharge of $82 \mathrm{~m}^{3} / \mathrm{s}$, average peak annual discharge of $541 \mathrm{~m}^{3} / \mathrm{s}$, and average base flow of $17 \mathrm{~m}^{3} / \mathrm{s}$ (based on records from USGS gauge no. 12358500). Dominant shrub and tree species include Populus trichocarpa, Alnus spp., Salix spp., $P i$ - cea engelmannii, Pseudotsuga menziesii, and Abies lasiocarpa (Mouw 2001).

Nyack is $8 \mathrm{~km}$ long and $3 \mathrm{~km}$ wide and is delineated on the up- and downstream ends by bedrock knick points (Fig. 1). The river flows through depositional shelves between these knick points and creates a braided channel system. Below the upstream knick point a losing reach occurs where $20-30 \%$ of the surface flow enters a shallow alluvial aquifer. Hyporheic water travels through the alluvia and moves preferentially along buried courses of abandoned river channels. Interstitial flow returns (upwells) to surface flow upstream of the lower (downstream) knick point. Within the gaining reach, 15-25\% of the river flow is upwelling groundwater from the alluvial aquifer (Poole et al. 2002). This upwelling water creates spring brooks, ponds, and wetlands that characterize the floodplain. Hence, two discrete reaches, one losing and one gaining, were available for analysis of cottonwood growth (Fig. 1). Be- 
tween these two reaches, the geohydrology is seasonally transitional with spatially variable vertical hydraulic gradients (Poole et al. 2002).

\section{Tree growth and leaf tissue analyses}

Cottonwood growth was determined as a relationship between tree basal area and tree age. We established 32 plots (each $200 \mathrm{~m}^{2}$ ), 16 plots in the losing reach and 16 plots in the gaining reach. Within each plot, 12-20 cottonwood trees were randomly selected for measurement of basal area and tree age. During the summer of 2000 , a total of 208 trees were sampled in the losing reach and 194 trees in the gaining reach. Obvious stump sprouts and root suckers were not measured, and plots were not established in regions with evidence of beavers. Tree diameter was measured at breast height, and basal area was calculated from the diameter. Tree cores were extracted from the trees at $30 \mathrm{~cm}$ aboveground using a Suunto increment borer (12 mm $\times 46 \mathrm{~cm}$; Suunto Oy, Vantaa, Finland). Small trees were cut at $30 \mathrm{~cm}$ aboveground. Where trees were cut, fewer (7-10) trees were sampled. Cores were prepared per Phipps (1985). Tree age was determined by counting annual rings on the increment cores. We considered the plot as the experimental unit and averaged the tree age and basal area on a per plot basis to overcome some of the errors associated with aging cottonwoods (e.g., Mahoney et al. 1991).

Tree age was related to tree size using a linear regression model that included all of the trees sampled. To test the hypothesis that basal area differed between the losing and the gaining reach, an analysis of covariance (ANCOVA) between basal area and tree age was conducted for trees in those two reaches using the mean basal area and tree age within each plot. ANCOVA was calculated by a linear regression model using the statistics program SPSS (1997). Basal area was considered the response variable, tree age the covariate, and position (losing reach vs. gaining reach) were the categorical predictors. The variables were log transformed to meet assumptions for regression models (Zar 1999).

Carbon (C), nitrogen (N), and phosphorus (P) compositions of cottonwood leaves were determined from 15 trees in the losing reach and 14 trees in the gaining reach during July 2002. Leaves were obtained from the top of the canopy of trees that were $\sim 2 \mathrm{~m}$ tall (tree age $10-12$ years). The leaves were dried at $60^{\circ} \mathrm{C}$ for 48 h. C:N ratios were determined using high-temperature combustion (Carlo-Erba NV $2100 \mathrm{CHN}$ analyzer [Milan, Italy]). To measure total phosphorus, the leaves were ashed and analyzed on a Technicon AutoAnalyzer (Technicon Industrial Systems, Tarrytown, New York, USA) following Murphy and Riley (1962).

\section{Measurement and analyses of variables influential to growth}

Biological and physical variables that might contribute to differences in cottonwood growth between reaches included plot elevation above river at base flow, depth of fine sediments, cottonwood stem density, and the change in water table elevation over one growing season. Plot elevations relative to the river at base flow (base flow $=18 \mathrm{~m}^{3} / \mathrm{s}$ ) were surveyed in September 2000 using a Leica laser theodolite (model 6500; Leica Geosystems AG, Heerbrugg, Switzerland). The depths of fine sediments were measured from a soil pit dug at the center of each plot. Pits were dug until gravel or cobble was reached, and the depth of sediment from the ground surface to the first layer of coarse material was recorded as the depth of fine sediments. Cottonwood density was determined by a count of the number of cottonwood trunks within the area of each plot.

Surface- and groundwater elevations were measured over one growing season to quantify variation in water table elevation between the losing and gaining reach. A datalogger and pressure transducer were installed at the upstream end of the floodplain to continuously record river stage. Piezometers $(3 \mathrm{~cm} \times 1.7 \mathrm{~m}$ polyvinyl chloride plastic pipe) were used to monitor the profile of the water table in the riparian forest (Gordon et al. 1993). Eleven piezometers were placed in the losing reach of the floodplain and eight were placed in the gaining reach. Water levels in the piezometers were measured, using a tape measure and water-soluble pen, from May to July 2000 or until the piezometers went dry. A simple linear regression of groundwater river stage was used to calculate water table decline during the growing season.

To determine if biological (tree density) and physical (depth to fine sediments, change in water table elevation, plot elevation) variables differed between reaches, the values for plots were compared between the losing reach and the gaining reach using a simple factorial ANOVA (SPSS 1997). Basal area was the dependent variable, the treatments were losing and gaining conditions, and age was the covariate.

\section{RESUlts}

\section{Tree growth and leaf tissue analysis}

Across Nyack Flood Plain, cottonwood age was positively correlated with tree size, and tree age was a significant predictor of tree basal area (Fig. 2a). Some other studies (e.g., Mahoney et al. 1991) have found that tree size is often not correlated with tree age in cottonwood. Despite the overall strong relationship, trees in the gaining reach tended to deviate positively from the regression line, and trees in the losing reach deviated negatively from the regression line.

Trees in the gaining reach had larger basal areas than trees in the losing reach at a given age (Fig. 2b). We compared the slopes of the regression lines for the mean tree age and the mean tree basal area from each plot for the losing and the gaining reaches. The slopes of the regression lines were indistinguishable $\left(F_{1,28}=\right.$ $0.044, P=0.835)$. The intercepts of the regression lines 

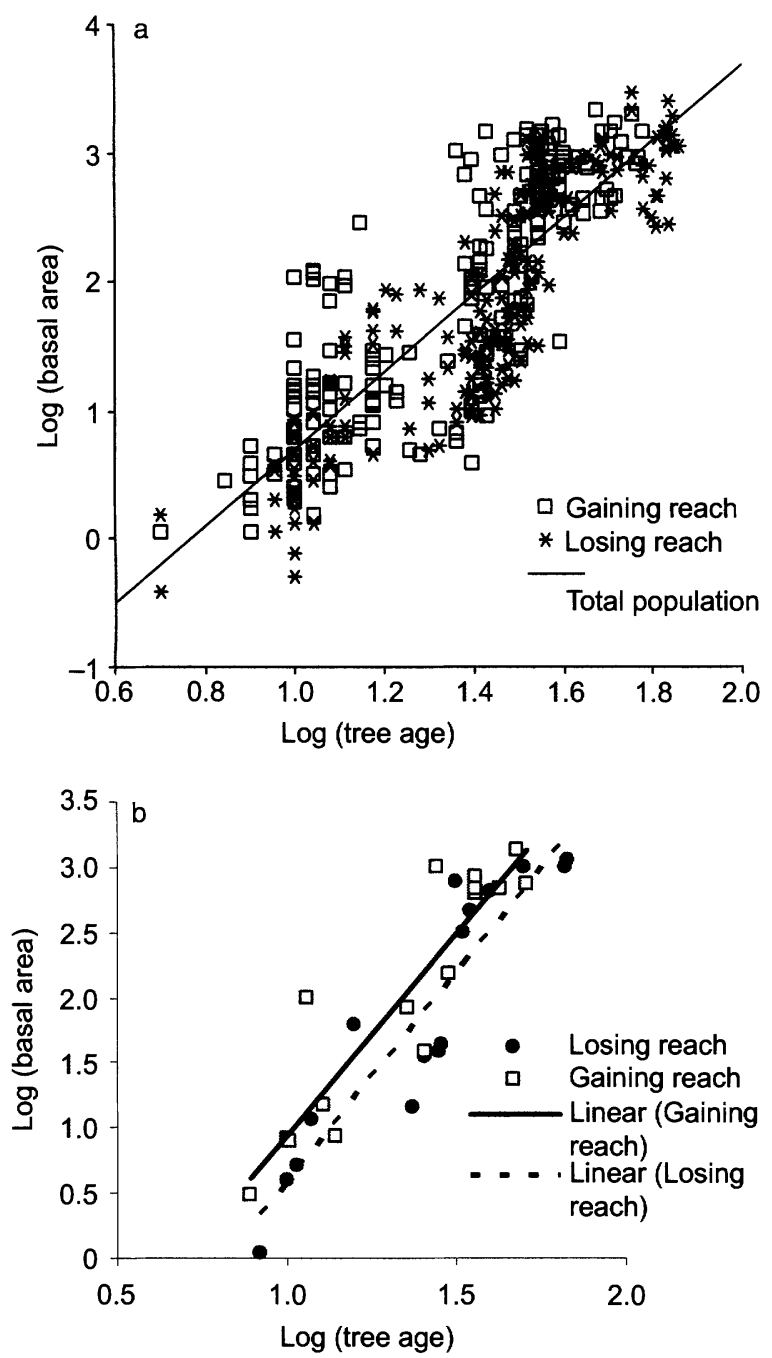

FIG. 2. (a) Log-adjusted basal area $\left(Y\right.$, measured in $\left.\mathrm{cm}^{2}\right)$ as a function of log-adjusted tree age ( $X$, measured in years) for Populus trichocarpa growing on the Nyack Floodplain. Data points are trees from the losing $(N=208)$ and gaining $(N=194)$ reaches (total $=402$ trees). Regression for all trees, $Y=2.97[ \pm 0.09] X-2.27[ \pm 0.13], R^{2}=0.72, F_{1,401}=$ $1020, P<0.0001$. Values in square brackets are \pm 1 SE. (b) Log-adjusted mean basal area $\left(Y\right.$, measured in $\left.\mathrm{cm}^{2}\right)$ as a function of log-adjusted mean tree age ( $X$, measured in years) for Populus trichocarpa growing in the losing and gaining reaches of Nyack Flood Plain. Means for each plot were calculated by averaging the basal area and tree age for all trees growing within the plot. Losing reach regression, $Y=3.18[ \pm 0.36]$ $X-2.59$ [ \pm 0.52 ] $, R^{2}=0.84, F_{1,15}=77.65, P<0.0001$. Gaining reach regression, $Y=3.06[ \pm 0.37] X-2.11$ [ \pm 0.51$], R^{2}=0.82, F_{1,15}=69.197, P<0.0001$. The slopes of the regression lines for the losing and the gaining reach are homogeneous $\left(F_{1,28}=0.04, P=0.835\right)$. The intercept for the gaining reach is significantly greater than the intercept for the losing reach $\left(F_{1.29}=5.14, P=0.031\right)$.

were significantly different, with the line for the gaining reach lying above the line for the losing reach (Fig. $2 \mathrm{~b})$. The same pattern held when all trees $(N=402)$ were compared $\left(F_{1.399}=30.99, P<0.0001\right)$. This sug- gests that at a given age, a tree in the gaining reach will have a basal area approximately twice the basal area of the same age tree in the losing reach. This is a proportional increase that holds over the range of ages in this study, though there is a tendency for the slopes to begin converging at older ages. For example, a 10-yr-old tree has a predicted basal area of $4 \mathrm{~cm}^{2}$ in the losing reach and $9 \mathrm{~cm}^{2}$ in the gaining reach. A 50yr-old tree has a predicted basal area of $654 \mathrm{~cm}^{2}$ in the losing reach compared to $1236 \mathrm{~cm}^{2}$ in the gaining reach.

Cottonwood leaves in the gaining reach had more nitrogen in their tissues than leaves in the losing reach, suggesting the trees in the gaining reach had access to more nitrogen. Leaf samples came from trees that were $\sim 12$ yr old. Leaves in the losing reach had significantly higher $\mathrm{C}: \mathrm{N}$ than leaves in the gaining reach (Table 1). $\mathrm{C}: \mathrm{P}$ and $\mathrm{N}: \mathrm{P}$ did not differ between reaches, suggesting that phosphorus is not as limiting in this ecosystem as nitrogen.

The density of cottonwood trees within a plot was greater in the losing reach compared to the gaining reach (Table 1). This difference in density between the reaches may be a response to the different growth rates, with faster growing trees thinning more rapidly than slow-growing trees. Between both reaches, an exponential decline of tree density with plot age was observed. Young cottonwood stands were very dense $(>10000$ stems/ha) and thinned rapidly between 10 and $20 \mathrm{yr}$. Stem exclusion ceased at $\sim 30 \mathrm{yr}$, and densities in older stands were relatively constant and lower $(<1300$ stems/ha). Partial correlation coefficients that controlled for tree age revealed that density was negatively correlated with basal area $(r=-0.52, P=$ 0.009 ) across both reaches.

Alternatively, lower densities of cottonwoods may contribute to the faster growth that was observed in the gaining reach, with trees that establish in sites with lower plant densities having greater access to resources. Understory plants more tolerant of saturated alluvium, such as red osier dogwood (Cornus stolonifera), alder (Alnus spp.), and willow (Salix spp.), were abundant throughout the gaining reach and much less common in the losing reach. Conditions in the gaining reach of Nyack may favor colonization by species other than cottonwood, thus reducing cottonwood densities. For example, on Nyack, as well as on the Talkeetna River in Alaska, Mouw (2001) found that areas near upwelling groundwater and with fine-textured alluvium had the greatest vascular plant species richness within the floodplains. Cottonwood densities may differ between the reaches as a result of the occurrence of other species interspersed with cottonwoods in the gaining reach.

\section{Variables influential to growth}

On average, soils in the gaining reach had $26 \mathrm{~cm}$ more fine sediments (defined as particle size smaller than gravel) than soils in the losing reach (Table 1), 
TABlE 1. Adjusted mean values (with $1 \mathrm{SE}$ in parentheses) for variables in the losing and the gaining reaches of Nyack Flood Plain.

\begin{tabular}{|c|c|c|c|c|c|}
\hline Dependent variable & Covariate & Unit & $\begin{array}{l}\text { Losing } \\
\text { reach }\end{array}$ & $\begin{array}{l}\text { Gaining } \\
\text { reach }\end{array}$ & $P$ \\
\hline $\mathrm{C}: \mathrm{N}$ & & tree $[15,14]$ & $40.98(1.6)$ & $35.26(1.5)$ & 0.016 \\
\hline $\mathrm{C}: \mathrm{P}$ & & tree $[15,14]$ & $939.76(67.3)$ & $892.42(58.54)$ & 0.600 \\
\hline $\mathrm{N}: \mathrm{P}$ & & tree $[15,14]$ & $23.24(1.7)$ & $25.27(1.4)$ & 0.368 \\
\hline Density (no. stems/ha) & age & plot $[16,16]$ & 4411 & 2754 & 0.009 \\
\hline Fine sediment depth $(\mathrm{cm})$ & age & plot $[16,16]$ & 55.21 & 80.82 & 0.043 \\
\hline Elevation above base flow (m) & & plot $[16,16]$ & $1.93(0.14)$ & $1.94(0.13)$ & 0.991 \\
\hline Change in water table elevation $(\mathrm{cm})$ & & wells $[11,8]$ & $146.07(11.71)$ & $92.31(14.82)$ & 0.010 \\
\hline
\end{tabular}

Notes: Numbers in square brackets represent the number of samples in the losing reach and gaining reach, respectively. $P$ values in boldface are significant.

which might positively influence the water-holding capacity and capillary fringe of soils in the gaining reach. The depth of fine sediments was correlated with the age of cottonwoods within a plot $(r=0.483, P<0.01$, $N=32$ plots), and was significantly greater in the gaining reach (Table 1). The depth of fine sediments also was correlated with tree basal area $(r=0.48, P$ $=0.007$ ). However, the elevations of plots relative to base flow did not differ between reaches, nor did they increase with cottonwood age.

Measurements of water table elevations throughout the growing season showed a significantly greater decline in water table elevation in the losing reach (Table 1). The changes in the water table elevation were negatively correlated with tree basal area $(r=-0.88, P$ $=0.009$ ). These measurements of water table elevations in the upper and lower reaches conformed to the pattern of regional losing and gaining (areas delineated in Fig. 1) on Nyack that has been documented repeatedly over the last decade (Poole et al. 2002).

\section{Discussion}

We demonstrated a very large difference in tree growth between downwelling and upwelling reaches of this expansive floodplain. On Nyack, cottonwood trees in the gaining reach have basal areas that are twice the area of those in the losing reach. Differences in seasonal water table elevation between reaches and the strong correlation between water table decline and tree size suggests that groundwater availability affects cottonwood growth. Groundwater availability has been demonstrated to influence cottonwood growth in numerous studies elsewhere (e.g., Busch and Smith 1995, Mahoney and Rood 1998, Scott et al. 1999, Horton et al. 2001).

The difference in seasonal water table elevation between reaches measured on Nyack in the summer of 2000 would likely not limit the growth of mature trees with expansive root networks. However, seedlings and young trees in the losing reach of Nyack experienced $150 \mathrm{~cm}$ or more decline in the water table by the end of the growing season, compared to the gaining reach where the water table remained much closer to the surface (Table 1). Under ideal conditions, the roots of cottonwood seedlings may grow $0.5-1 \mathrm{~cm} / \mathrm{d}$ and up to $100 \mathrm{~cm}$ in the first year (Mahoney and Rood 1998). Hence, the observed difference in water table elevations on Nyack likely substantially limited growth in the losing reach. Moreover, river flow during the summer of our measurements (2000) remained comparatively high; water availability would be more limiting in the gaining reach in drier years and extreme in the losing reach. The higher water table in the gaining reach likely benefits cottonwood seedlings every year that the hydrograph produces a recruitment opportunity, and likely reduces drought stress in mature trees during very dry years.

Leaf nitrogen content likewise was significantly higher for trees in the gaining reach. Upwelling water on this floodplain has up to an order of magnitude greater concentrations of nitrate and soluble reactive phosphorus (Bansak 1998, Ellis et al. 1998). Studies elsewhere also documented substantially higher plant growth nutrients in upwelling water that were correlated with localized increases in aquatic primary productivity (Ford and Naiman 1989, Valett et al. 1994, Clinton et al. 2002).

We believe that trees in the gaining (upwelling) reach have greater access to resources promoting growth than in the losing (downwelling) reach. Compared to the losing reach, the gaining reach was characterized by lower stem densities, deeper layers of fine sediments, and a higher water table. Our analysis of $\mathrm{C}: \mathrm{N}$ supports the hypothesis that the trees have greater access to nutrients in the gaining reach, but these differences may be confounded by variations in texture of alluvia between the reaches. The cottonwood trees at Nyack may respond to greater availability of water, an increased supply of nutrients, variations in soil texture, or an interaction of these components in more spatially explicit ways than we have quantified herein. Nonetheless, fertilization of riparian vascular plants likely occurs along hyporheic flow paths in a nutrient gradient context on expansive alluvial floodplains, as at Nyack. The important implication is that hyporheic flow may control tree growth and leaf quality, thereby influencing soil and aquatic food webs of alluvial floodplains. 


\section{ACKNOWLEDGMENTS}

We thank Jake Chaffin, Mark Lorang, Jason Mouw, Philip Ramsey, Craig Stafford, and Diane Whited for assistance. Jeff Braatne, Ragan Callaway, Mike Merigliano, Arthur McKee, Vicki Watson, and two anonymous reviewers provided insightful comments on the manuscript. Thanks to the John Dalimata family for access to the study site. Funding was provided by the U.S. Bureau of Reclamation, NSF Biocomplexity Award EAR 0120523 and an NSF Integrative Graduate Education and Research Training Award, DGE 9972810.

\section{Literature Cited}

Bansak, T. S. 1998. The influence of vertical hydraulic exchange on habitat heterogeneity and surficial primary production on a large alluvial floodplain of the Middle Fork Flathead River. Thesis. University of Montana, Missoula, Montana, USA.

Braatne, J. H., S. B. Rood, and P. E. Heilman. 1996. Life history, ecology, and conservation of riparian cottonwoods in North America. Pages 57-85 in R. F. Stettler, H. D. Bradshaw, Jr., P. E. Heilman, and T. M. Hinckley, editors. Biology of Populus and its implications for management and conservation. NRC Research Press, National Research Council of Canada, Ottawa, Ontario, Canada.

Bradley, C. E., and D. G. Smith. 1986. Plains cottonwood recruitment and survival on a prairie meandering river floodplain, Milk River, southern Alberta and northern Montana. Canadian Journal of Botany 64:1433-1442.

$\rightarrow$ Busch, D. E., and S. D. Smith. 1995. Mechanisms associated with decline of woody species in riparian ecosystems of the southwestern U. S. Ecological Monographs 65:347370.

Clinton, S. M., R. T. Edwards, and R. J. Naiman. 2002. Forest-river interactions: influence on hyporheic dissolved organic carbon concentrations in a floodplain terrace. Journal of the American Water Research Association 38:619-631.

Craft, J. A., J. A. Stanford, and M. Pusch. 2002. Microbial respiration within a floodplain aquifer of a large gravelbed river. Freshwater Biology 47:251-261.

Dahm, C. N., N. B. Grimm, P. Marmonier, H. M. Valett, and P. Vervier. 1998. Nutrient dynamics at the interface between surface waters and groundwaters. Freshwater Biology 40:427-451.

Ellis, B. K., J. A. Stanford, and J. V. Ward. 1998. Microbial assemblages and production in alluvial aquifers of the Flat head River, Montana, USA. Journal of the North American Benthological Society 17:382-402.

Elser, J. J., W. F. Fagan, R. F. Denno, D. R. Dobberfuhl, A Folarin, A. Huberty, S. Interlandi, S. S. Kilham, E. McCauley, K. L. Schulz, E. H. Siemann, and R. W. Sterner 2000. Nutritional constraints in terrestrial and freshwater food webs. Nature 408:578-580.

Ford, T. E., and R. J. Naiman. 1989. Groundwater surface $\rightarrow$ water relationships in boreal forest watersheds: dissolved organic-carbon and inorganic nutrient dynamics. Canadian Journal of Fisheries and Aquatic Sciences 46:41-49.

Gordon, N. D., T. A. McMahon, and B. L. Finlayson. 1993. Stream hydrology. John Wiley and Sons, Chichester, UK.

Grimm, N. B., and S. G. Fisher. 1984. Exchange between surface and interstitial water: implications for stream metabolism and nutrient cycling. Hydrobiologia 111:219-228. $\rightarrow$ Horton, J. L., T. E. Kolb, and S. C. Hart. 2001. Physiological response to groundwater depth varies among species and with river flow regulation. Ecological Applications 11: 1046-1059.

Mahoney, J. M., P. Koegler, and S. B. Rood. 1991. The accuracy of tree ring analysis for estimating the age of riparian poplars. Pages 25-30 in S. B. Rood and J. M. Mahoney, editors. The biology and management of southern Alberta cottonwoods. University of Lethbridge, Alberta, Canada.

Mahoney, J. M., and S. B. Rood. 1998. Streamflow requirements for cottonwood seedling recruitment-an integrative model. Wetlands 18:634-645.

Mouw, J. E. B. 2001. Floodplain plant diversity and conservation in regional and local contexts. Ph.D. Dissertation. University of Montana, School of Forestry, Missoula, Montana, USA.

Murphy, J., and J. P. Riley. 1962. Determination of phosphate in natural waters. Analytica Chimica Acta 27:31-36.

Petts, G. E., A. M. Gurnell, A. J. Gerrard, D. M. Hannah, B. Hansford, I. Morrissey, P. J. Edwards, J. Kollmann, J. V. Ward, and K. Tockner. 2000. Longitudinal variations in exposed riverine sediments: a context for the ecology of the Fiume Tagliamento, Italy. Aquatic Conservation-Marine and Freshwater Ecosystems 10:249-266.

Phipps, E. L. 1985. Collecting, preparing, crossdating and measuring tree increment cores. Water-Resources Investigations Report Number 85-4148. U.S. Geological Survey, Lakewood, Colorado, USA.

Poole, G. C., J. A. Stanford, C. A. Frissell, and S. W. Running. 2002. Three-dimensional mapping of geomorphic controls on flood-plain hydrology and connectivity from aerial photos. Geomorphology 48:329-347.

Scott, M. L., J. M. Friedman, and G. T. Auble. 1996. Fluvial process and the establishment of bottomland trees. Geomorphology 14:327-339.

Scott, M. L., P. B. Shafroth, and G. T. Auble. 1999. Responses of riparian cottonwoods to alluvial water table declines. Environmental Management 23:347-358.

$\rightarrow$ Segelquist, C. A., M. L. Scott, and G. T. Auble. 1993. Establishment of Populus deltoides under simulated alluvial groundwater declines. American Midland Naturalist 130: 274-285.

SPSS. 1997. SPSS Version 7.5 for Windows. SPSS, Chicago, Illinois, USA.

Stanford, J. A., and A. R. Gaufin. 1974. Hyporheic communities of two Montana Rivers. Science 185:700-702.

Stanford, J. A., and J. V. Ward. 1988. The hyporheic habitat of river ecosystems. Nature 335:64-66.

Triska, F. J., J. H. Duff, and R. J. Avanzino. 1993. Patterns of hydrological exchange and nutrient transformation in the hyporheic zone of a gravel-bottom stream: examining terrestrial-aquatic linkages. Freshwater Biology 29:259-274.

Valett, H. M., S. G. Fisher, N. B. Grimm, and P. Camill. 1994. Vertical hydrological exchange and ecological stability of a desert stream ecosystem. Ecology 75:548-560.

Wondzell, S. M., and F. J. Swanson. 1996. Seasonal and storm dynamics of the hyporheic zone of a 4th-order mountain stream. II. Nitrogen cycling. Journal of the North American Benthological Society 15:20-34.

Zar, J. H. 1999. Biostatistical Analysis. Fourth edition. Prentice Hall, Upper Saddle River, New Jersey, USA. 